\title{
Why do maternally inherited microorganisms kill males?
}

\author{
GREGORY D. D. HURST* \& MICHAEL E. N. MAJERUS \\ Department of Genetics, Downing Street, Cambridge CB2 3EH, U.K.
}

\begin{abstract}
Maternally-inherited male killing microorganisms are known in a number of insect species. We here discuss the evolutionary reasons for such behaviour through examining the ongoing dynamics of these elements. In cases where death occurs late in the life cycle, horizontal transmission associated with male death occurs but in others no such direct advantage to killing the individual appears to exist. The evidence that early male killing is analogous to primary sex ratio distortion through increasing the fitness with respect to producing females from increases in resources to surviving (female) offspring and through the prevention of inbreeding is discussed. The early life history of many of these species suggests an early resource advantage may accrue from male killing. Inbreeding avoidance appears to be an important factor in at least two cases. The potential for horizontal transmission to maintain these elements is also discussed. It is concluded that male killing appears to be an adaptive strategy for the microorganism in most cases.
\end{abstract}

Keywords: cytoplasmic microorganisms, horizontal transmission, inbreeding avoidance, male killing, maternal inheritance, resource redistribution.

\section{Introduction}

A wide variety of insect taxa is now known to harbour male killing microbes; cytoplasmically inherited microorganisms which kill the sons of individuals bearing them and are only transmitted through the female line. We wish to address here the reasons for killing males.

Three main advantages have been hypothesized to accrue from killing males. First, killing males may produce an increase in available resources to sibling females which bear a clonal relative of the bacterium (Skinner, 1985; Hurst, 1991, 1993). Such an increase in resources may be either direct, from allowing the consumption of the soma of male eggs, or indirect, from the reduction of competition suffered by sisters of such individuals. Such resource reallocation is envisaged to increase the fitness of the daughters, the line through which the microbe may pass vertically, and therefore the microbe itself. Second, it has been hypothesized that an advantage is gained from the avoidance of inbreeding (Poulton, 1928; Lewis, 1941; Lus, 1947a; Werren, 1987; Ebbert, 1991). Females which bear the microbe will have few if any brothers, and are thus less likely to inbreed. Their daughters are thus less likely to suffer from inbreeding depression. Third, male death may be a mechanism for producing the horizontal

\footnotetext{
${ }^{*}$ Correspondence.
}

transfer of the microbe out of the male lineage, through which it cannot pass vertically, into other organisms (Hurst, 1991 and inclusive references).

Male killing will be adaptive to the microbe if an increase in survival of the microbe results from male death. That is to say, the increase from the above sources must be greater than any decrease from horizontal transmission that may result from killing males.

Hurst (1991) recently distinguished two types of male killing behaviour, separated as to timing: early male killing, where death occurs during embryogenesis or the first instar, and late male killing, where male death occurs during the fourth instar or later. In the case of late male killing, as observed in mosquitoes, it was pointed out that male death is the result of the proliferation of the parasite within the tissues. Following death, spores of the parasite are dispersed into the environment. The ability of these particles to infect other host species was noted, and evidence of the reciprocal transfer of the parasite from these intermediate' hosts was discussed. In these cases, the selective advantage of killing males is seen to be the third of these types: male killing produces horizontal transfer of the element out of the male lineage, through which it cannot be passed, to other lineages.

The dynamics of early male killing are not so well understood. Resource reallocation and the prevention of inbreeding by remaining females which bear the 
element have been suggested as advantages of this behaviour, and horizontal transfer of the element following male death has not been discounted. The existence of horizontal transfer of the male killing elements independently of male killing activity has also been discussed as a factor in the dynamics of these elements (Uyenoyama \& Feldman, 1978).

We review how far hypotheses concerning the advantages of early male killing are vindicated in the light of ecological data. We consider only cases where firm evidence of male killing as the cause of sex ratio bias has been obtained, and either evidence of heritability or microbial action has been found. Other cases where cytoplasmic male killers are acting almost certainly exist, but are not dealt with here (see Hurst, 1993 for details). We start by reviewing the known data on factors producing a decrease in male killers in the species in which they are found.

\section{Factors producing a decrease in male killers in the population}

Current data on known cases of male killing suggest that in nearly all cases either inefficient transmission of the element between generations, or effects of the element on fecundity, exist (see Hurst, 1993 for full review: summary in Table 1). The one possible exception is Hypolimnas bolina where non-transmission of the element has never been observed despite over 150 progeny of sex ratio broods being successfully mated. This may indicate that this is in fact caused by a Y-linked gene. Such a gene would have identical dynamics to cytoplasmically inherited microorganisms with fidelity of transmission. The transmission efficiency observed in other cases varies from near perfect (e.g. Estigmene acrea) to relatively inefficient (e.g. Adalia bipunctata and Epiphyas postvittana). In no case is there good evidence of a positive effect of infection on fecundity, although one may derive from an increase in available resources in Nasonia vitripennis (Skinner, 1985; Werren et al., 1986). There seems little evidence that such elements produce any mutualistic advantage. Laboratory investigations frequently suggest a decrease in fecundity and an increase in sterility of infected females, indicating that infection with male killers, in the absence of advantages deriving from killing males, is detrimental. How such laboratory observations relate to decreases in fecundity or fertility in the field is uncertain.

The continued existence of male killing elements in spite of the above losses suggest some other processes must be important in the dynamics of these microorganisms. Examination of the evidence concerning such processes may allow insight into considerations of the adaptive nature of male killing.

\section{Evidence for a resource advantage}

The ecology of the host species during early development is critical in determining the extent of resource advantage that may be obtained through male killing. The extent to which male killing releases resources to siblings, and the effect of increasing resources on the fitness of neonate siblings, are crucial in determining the extent of any resource advantage of male killing. If neonate survivorship is affected by access to a limiting resource then male killing will be advantageous if male killing releases such resources to siblings (which bear the male killing element) above non-siblings (which may not) (Hurst, 1991). We therefore note the evidence for the sources of early mortality of neonates and the level of sibling interaction between neonates.

\section{Oncopeltus fasciatus (Hemiptera: Lygaediae)}

Eggs of Oncopeltus fasciatus, the large milkweed bug, are laid in clutches of 2-38 eggs on a variety of milkweed species (Andre, 1934). Females are inhibited from ovipositing on plants within a patch already bearing eggs, and thus egg clutches tend to be dispersed between plants (Sauer \& Feir, 1973). Unhatched eggs are consumed (Dingle, 1968). The nymphs disperse and search for the seeds of the milkweed plant on which they feed. These seeds are often enclosed in a tough pod, and the first instar nymphs have a restricted choice in terms of the pods that they can use when compared with later stages: they may obtain seeds from open, damaged or thin walled pods (Ralph, 1976). The survivorship of first and second instar nymphs is poor (Sauer \& Feir, 1973). This probably results from the limited availability of suitable pods to nymphs and the low searching ability of neonates (Ralph, 1977). As Ralph (1977) states, "the more pods within their search radius, the greater the nymphs' chances of finding a suitable feeding spot, and the shorter their exposure to the inhospitable world of non-hosts'. In the absence of seed food, unopened pods may also be used as a food stuff. Survival on unopened pods is poor, but gregarious feeding by sibling larvae may increase the efficiency of feeding (Bongers \& Eggermann, 1971; Sauer \& Feir, 1973; Ralph, 1976). Seeds from opened pods are utilized as efficiently by singles as by groups of larvae.

$O$. fasciatus appears to represent a case where the mortality of neonates is high owing to a low searching capacity and a restricted food source. It seems likely that the consumption of dead male eggs will increase neonate survivorship and therefore search distance, thus increasing the probability that nymphs successfully encounter a suitable pod. The extent of such an advantage is hard to ascertain and will depend on the 


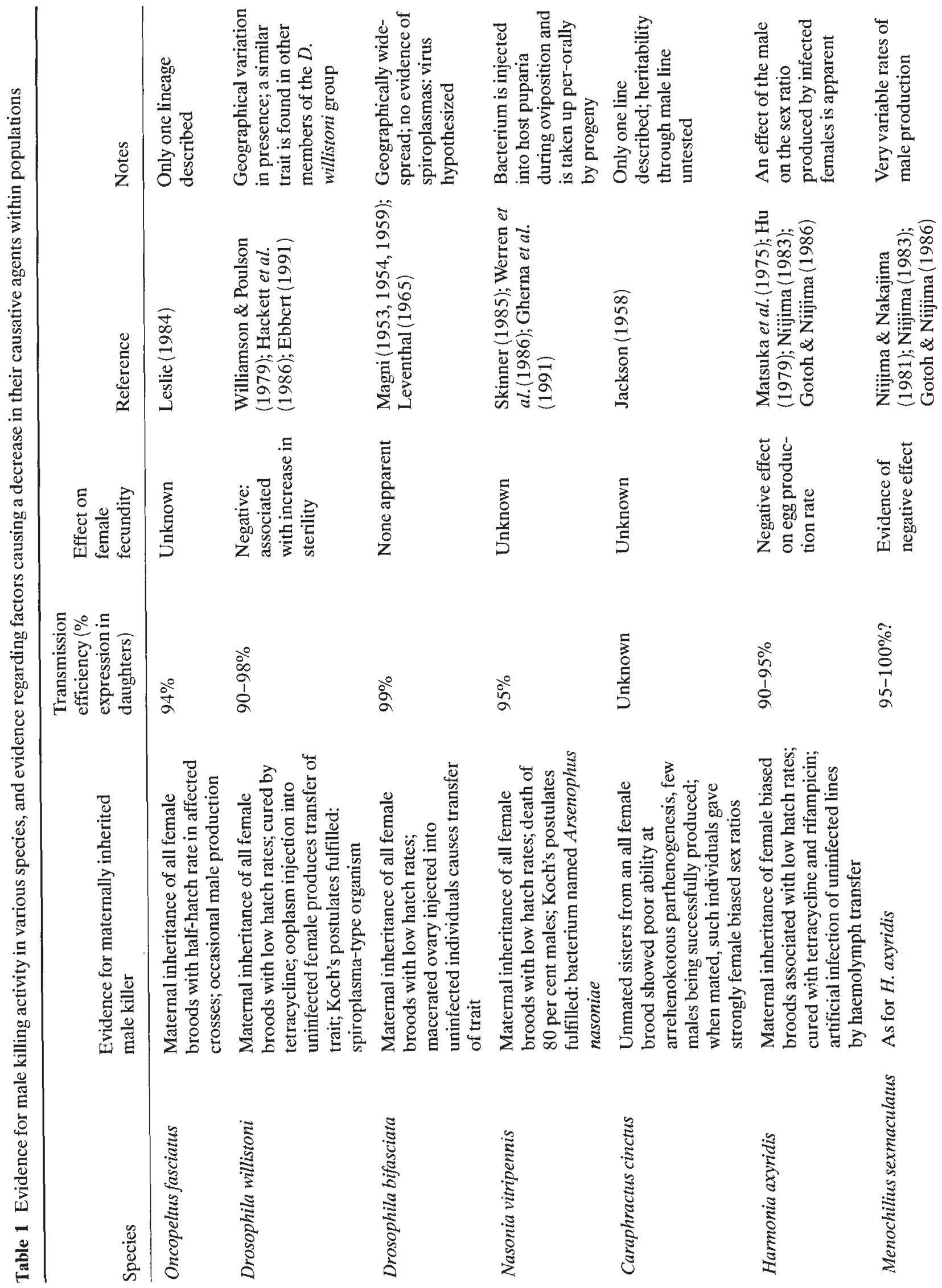




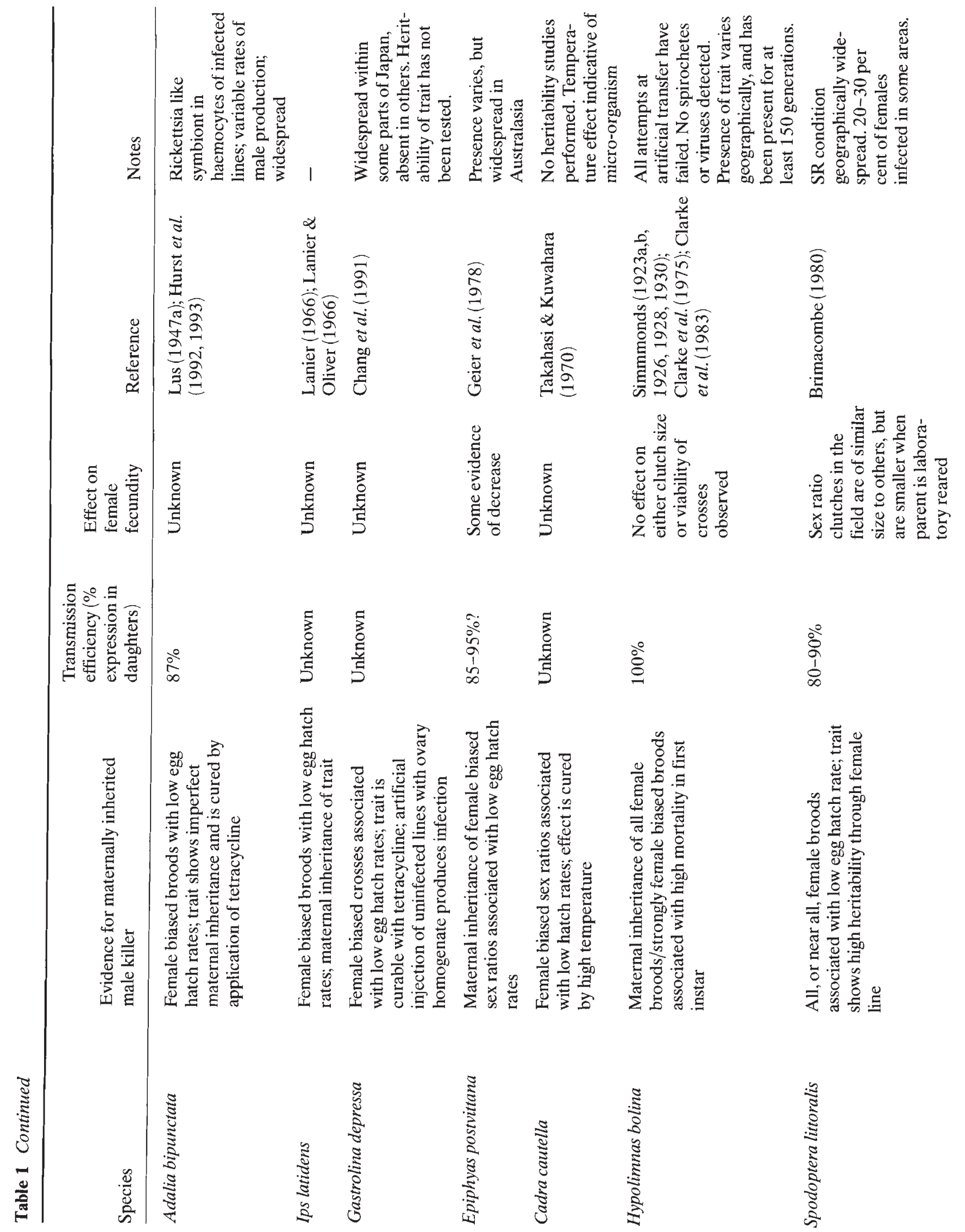


presence of suitable pods on the host plants. If a particular plant has many pods bearing available seed, then no difference between the survivorship of females from male killed and normal clutches is expected: all larvae will find food. If suitable pods are rare, then nymphs from male killed clutches may have an increased probability of finding such pods, and male killing will result in an increase in female survivorship. If there are no pods in which seed are available, then the advantage obtained through gregariousness will be reflected in increased survivorship of females from normal clutches over ones from male killed clutches. However, such a situation is probably rare. The extra resources from egg consumption will probably have a positive effect on the survivorship of neonate females in most instances.

\section{Drosophila willistoni group (Diptera: Drosophilidae)}

The members of this group which bear male killing agents live in South America, and lay their eggs in fruit. Collections of fruit from Brazilian islands showed only a low level of $D$. willistoni within fruit compared with their potential infestation as determined in the laboratory (Birch \& Battaglia, 1957). It thus seems likely that the amount of resources within a fruit do not affect survivorship. Population cage experiments also failed to show any significant resource advantage to females from male killed clutches (Ebbert, 1991). However, Birch \& Battaglia (1957) also noted that survivorship may depend on the condition of the fruit: only fermented fruit a few days old yielded flies. As fruit ages and becomes dry and baked, survivorship decreases markedly. If sibling larvae interact in a scramble way after hatching, thus increasing development time, then early male killing would have a positive fitness consequence not easily detected in the laboratory: surviving females from infected broods might develop more quickly, and thus have a greater probability of emergence from their host fruit.

The presence of an early resource advantage in this species is uncertain. A study of the causes of larval death in the field and the effects of male killing on such mortality is required.

\section{Drosophila bifasciata (Diptera: Drosophilidae)}

Drosophila bifasciata inhabits palearctic regions. It is known to oviposit in sap fluxes from trees (Kimura $e t$ al., 1977). Predation is considered to prevent Drosophila species at slime fluxes from reaching high densities at the breeding and feeding sites (Sokoloff, 1966). Larval densities are therefore probably low. Laboratory studies show that when reared in isolation, 
sex ratio females have similar development times to, but higher fecundity than, their non-sex ratio counterparts. However, when reared together under crowded conditions, they have decreased survivorship with respect to their normal counterparts (Ikeda, 1970). Crowding appears to have the reverse effect to that expected merely from a consideration of resources, and does not appear to be important in wild populations.

\section{Nasonia vitripennis (Hymenoptera: Pteromalidae)}

Nasonia vitripennis is a parasitoid wasp which lays eggs into single puparia of blow flies. A puparium may already be utilized by another individual, and may be used later by another adult. The bacterium, Arsenophus nasoniae, is transferred to these puparia during oviposition and taken up per-orally by the developing embryos (Werren et al., 1986). The larvae consume the soma of their host puparia and pupate.

The importance of resource diversion is not easily ascertained. It has been suggested that the death of males frees resources for remaining females, which will therefore develop into larger, more fecund adults (Skinner, 1985). However, the primary sex ratio of $N$. vitripennis is strongly female biased, so resource diversion will not be high. Although the death of females from overcrowding is known where multiple oviposition into single puparia is observed (Copland \& King, cited in King et al., 1969), the presence of a positive fitness effect on single ovipositions, although inherently plausible, is unproven.

\section{Caraphractus cinctus (Hymenoptera: Mymaridae)}

Caraphractus cinctus is an egg parasite of water beetles. A variable number of eggs are placed in each host egg. Up to 50 eggs may be laid in the comparatively large eggs of Dytiscus marginale, whereas eggs of Agapus species are more liable to contain two to three eggs. The larvae develop within their host egg without cannibalism. Significant mortality may occur during development, especially if the host egg has shown some development (Jackson, 1956, 1961).

This system, like that in $N$. vitripennis, appears to show some level of resource advantage to male killing. When laid in Dytiscus eggs, there is an appreciable mortality rate. When laid in Agapus eggs, brachypterus females, which are small and less long lived than their fully winged counterparts, may develop. Both of these are attributed to competition for resources. The level of such competition depends on two factors. First, egg load per host is inversely proportional to the availability of such eggs (Jackson, 1966). Second, the level of nutrients within the egg varies with the development of the host embryo (Jackson, 1961).

\section{Harmonia axyridis, Menochilius sexmaculatus, Adalia bipunctata (Coleoptera: Coccinellidae)}

These coccinellid beetles have similar ecologies. All lay eggs in clutches of up to 48 eggs. Eggs hatch, and first instar larvae devour the remaining unhatched eggs. In all three cases, eating an egg increases the survival time of neonates deprived of food and water (Banks, 1955; Kawai, 1978; Ng, 1986). An increase in survival time in the order of 75 per cent occurs on eating a male killed egg in A. bipunctata (G. D. D. Hurst et al., in prep). Larvae fed on an egg also move more rapidly, (M. F. Walker, 1962, unpublished data). On dispersal, the larvae search for, and attempt to capture, aphids on their host plant. In A. bipunctata, the mortality of larvae at this stage is probably very high, given the low area covered before death and the low success rate in capturing aphids when such encounters do occur (Banks, 1955; Dixon, 1970; Wratten, 1973, 1976).

A. bipunctata individuals which eat an egg show an increase in both survival time and speed. The area searched before death from starvation, and therefore the numbers of aphids encountered, is greater. The vulnerability of first instar larvae to death by starvation before finding an aphid suggests that the survival time (and therefore search area) advantage, obtained through eating an egg, will be manifested in a fitness advantage for neonates which eat a sibling egg. The precise advantage will depend crucially on the variance in aphid density over time and space. At some times the aphid density around a clutch will be sufficient to allow a high level of survivorship without an egg meal whereas, at others, clutches may be laid remote from regions of high aphid density, or at times when aphids are scarce. Field evidence suggests that oviposition occurs before peak aphid densities to allow a sufficient aphid density for the successful development of later instars (Hemptine et al., 1992). The evidence, although circumstantial, strongly suggests a resource advantage to individuals from male killed clutches in $\mathrm{A}$. bipunctata. Osawa (1989) similarly discusses the role of egg cannibalism in increasing survivorship of neonate $H$. axyridis. Evidence in support of this thesis comes from Osawa's (1992) study of the evolution of sibling cannibalism. Larvae allowed to feed on varying numbers of eggs in the laboratory were released onto a citrus tree. Those allowed to feed on eggs had increased survivorship to the second instar, the magnitude of which depended on aphid density (Osawa, 1992). At first sight, this study provides evidence for a 100 per cent 
increase in fitness from the cannibalism for one egg. However, some caution must be taken in interpreting these results in the light of male killing behaviour. First, it was not male killed but living eggs that were used. This, given the varying nutritional value of coccinellid eggs over time (Agarwala, 1991), will create at least a small error in the precise usefulness of male killed eggs to larvae. Second, the eggs were fed to larvae which had dispersed from their clutch, not larvae before dispersal, as would be the case for male killed eggs. Third, the larvae were placed in the field after $24 \mathrm{~h}$ at $25^{\circ} \mathrm{C}$. This will create a selective force against individuals not allowed to eat an egg, their survival time in the absence of food averaging only $46 \mathrm{~h}$ compared with 95 $\mathrm{h}$ for individuals eating one or more eggs (Kawai, 1978). The proportionate decrease in time allowed for the newly dispersed larvae to catch their first aphid meal is therefore much larger for individuals not allowed to eat an egg, and the data on survivorship likely to be biased by this factor. Osawa's evidence does, however, provide good circumstantial evidence for an increase in survivorship from egg cannibalism. The level of such an advantage is, however, not measurable from this data set.

\section{Ips (Orthotomictus) latidens (Coleoptera: Scolytidae)}

Female I. latidens join the tunnel system of males, mate, and lay eggs. Two or three females may exist in the tunnel system of a single male, each female utilizing a separate gallery within the tunnel system. Egg tunnels are constructed within the gallery, and eggs laid singly in separate niches within egg tunnels. On average, egg tunnels contain 27 such niches within a gallery. Early interactions within the gallery system are therefore sibsib. The larvae hatch and develop within this tunnel system, feeding off the phloem tissue of the plant and passing through three instars before pupation. The phloem tissue is considered to be a limiting resource and responsible for the high level of mortality seen during the first two larval instars. Sibling cannibalism occurs, and is held to reflect the high level of competition for resources between siblings within an egg tunnel (Miller \& Borden, 1985). Competition may also exist between individuals of different matrilines within a harem (Kirkendall, 1989).

The system of tunnels with high levels of intersibling competition for resources in I. latidens suggests that an early resource advantage will exist for females from male killed clutches. Not only will the resources per female be higher in egg tunnels where males have been killed but also the number of cannibalizing older siblings will be fewer, and those that exist better fed and so less likely to be cannibalistic. This strongly suggests that a large resource advantage may accrue to daughters of females bearing a male killing element.

\section{Gastrolina depressa (Coleoptera: Chrysomelidae)}

Gastrolina depressa lay eggs in clutches of around 100. Neonates feed in groups after dispersal. Increases in group size increase the survivorship of individual larvae, although large differences are only apparent when low numbers are present in aggregations, and the change in aggregation size from 100 to 50 seen on male killing is unlikely to have any significant effect. The mortality of early instar larvae in wild populations is low, and is largely attributable to predation, parasitism and disease (Chang \& Morimoto, 1988). It is unknown whether $G$. depressa, like many other chrysomelids, shows egg cannibalism.

There appears to be no evidence for an early resource advantage. Interactions between larvae have a positive effect on fitness, and mortality from a lack of resources is low. Other aspects of the ecology of this beetle remain unexamined. The use of geographical variation in the level of the element may be useful in examining the factors maintaining it in the population.

\section{Epiphyas postvittana (Lepidoptera: Tortricidae)}

The light brown apple moth, E. postvittana, lays its eggs in clutches of around 34 on the tops of leaves of a wide variety of host plants (Danthanarayana, 1975). Dispersion occurs following hatching. It is unknown whether unhatched eggs are consumed. The mortality during dispersal is very high (MacLellan, 1973; Geier $\&$ Briese, 1980) and the first instar is considered the key stage (Danthanarayana, 1983). The larvae must create spin-ups, areas protected by silken threads from predators, before ecdysis to the second instar occurs (Danthanarayana, 1975). A finite number of such sites exist, and only one larva may occupy each area. Large numbers of neonates mutually interfere, and larvae unsuccessful in forming spin-ups must disperse to other sites, with high risk (Geier \& Briese, 1980).

Geier et al. (1978) suggest that the male killing element is maintained by the increased success of female neonates bearing the element in finding the scarce resource of spin-up sites in the absence of competition from their brothers.

\section{Cadra cautella (Lepidoptera: Pycitinae)}

The almond moth, $C$. cautella, is best known as a pest of stored products in temperate regions. Eggs are laid in clutches of up to 250 in the top of the grain, and sibling egg cannibalism has been observed. Food limita- 
tion may be an important constraint in such situations, and the presence of cannibalism at all stages of larval development is suggestive of competition between larvae (Gordon \& Stewart, 1988). The ecology of $C$. cautella in its ancestral setting is little studied. Eggs are laid in ripening fruit (Hill, 1987), but precise details of its population ecology were not found.

A resource advantage of sibling egg cannibalism seems probable, but the precise fitness effect of such a meal is not easy to quantify.

\section{Hypolimnas bolina (Lepidoptera: Nymphalidae)}

Hypolimnas bolina lays clutches of around 30 eggs on a wide variety of food plants (Vane-Wright et al., 1977). Larvae hatch and remain gregarious until the beginning of the third instar when they disperse (Mathew, 1888). Male death occurs largely during the first instar. The demography of $H$. bolina is not well characterized.

Clarke et al. (1975) observed that in the laboratory the number of adults emerging from sex ratio and nonsex ratio clutches is approximately equal, despite the death of nearly all the males in the former. This is taken as a possible indicator of decreased competition in sex ratio broods producing increased survivorship. The reality of such a situation in the field is, however, unknown.

\section{Spodoptera littoralis (Lepidoptera: Noctuidae)}

Spodoptera littoralis, the Egyptian cotton leaf worm, lays clutches of up to 1000 eggs on the underside of leaves of a wide variety of forbs, shrubs and trees. After hatching, all the larvae disperse at one time, and remain gregarious on the same host plant for the first few days (Bishara, 1934). The consumption of unhatched eggs is not recorded but the presence of cannibalism in later stages suggests that this might occur.

The importance of reduced competition between siblings has been suggested (Brimacombe, 1980). The only study found of the demography of $S$. littoralis suggested an increase in fitness from gregariousness (Zaher \& Moussa, 1961). However, an excess of food was provided in this study and the demography in field conditions may differ from this.

\section{Estigmene acrea (Lepidoptera: Arctiidae)}

The ecology of E. acrea, the salt marsh caterpillar, appears to be little known. Clutches of between 100 and 1000 eggs are laid on a variety of plants, from cotton to salt marsh plants (Hinds, 1904) and egg cannibalism is known in laboratory conditions (Earle \& MacFarlane, 1968). The neonates feed gregariously on the underside of leaves of their host plant for 5-6 days before dispersal (Young \& A Sifuentes, 1959). Whether such interactions are positive or negative is unknown.

There exists a resource advantage from egg cannibalism and possibly reduced competition. Whether such extra resources translate into an increase in survivorship is not clear.

\section{Summary}

The first prerequisite for a resource advantage to females from killing male progeny is that early interactions are mainly between siblings. In all of the species bearing these elements, eggs are laid either in clutches or in proximity to other older siblings: sib-sib interactions exist in all cases. Further to this, male killing must increase access to resources and therefore increase the survivorship of remaining females. It is necessary to show that the death of males has some positive effect on female survival. In many cases there is a clear resource advantage through the consumption of the soma of eggs containing dead males (coccinellid beetles, $C$. cautella, $O$. fasciatus, E. acrea). The evolution of sibling egg cannibalism in these species itself suggests some selective advantage to this behaviour, an advantage that will pass on to females from male killed clutches. In three cases ( $A$. bipunctata, $H$. axyridis, $O$. fasciatus), there is evidence beyond such argument by design. In these cases, the survivorship of neonates is dependent on their potential search area, a factor that egg cannibalism will certainly enhance. In other species, there is strong evidence of competition between siblings for resources, nutritional or otherwise. Ips latidens shows strong sibling competition for access to the phloem rich tissue. Siblings of $N$. vitripennis and $C$. cinctus share a common host, on which they feed. In E. postvittana, there may be limited sites for creating spin-ups to protect against predators. In other cases, although a high level of sibling interaction exists in early instars as a result of gregariousness, precise demographical data on the early instars are missing (E. acrea, S. littoralis and $H$. bolina). In three cases, however, it seems doubtful that resources play a significant role. Drosophila willistoni and D. bifasciata do not appear to be limited by food, and there appears to be a positive advantage to group size in the chrysomelid G. physarum, although the question of egg cannibalism is unresolved in this species.

\section{Inbreeding avoidance}

For a male killing element to gain an advantage through inbreeding avoidance, the species must show some 
level of both inbreeding and inbreeding depression. In some cases, levels of both of these have been described. In others, more anecdotal evidence from the ecology of adults is cited which bears on the question of inbreeding levels. It should be noted that a reciprocal relationship exists between the levels of inbreeding within a species and the levels of inbreeding depression that occur necessitating the measurement of both factors. Inbreeding increases selection against the deleterious alleles that cause inbreeding depression, such that species which show high levels of inbreeding show low levels of inbreeding depression. Evidence for the level of inbreeding takes the form of notes on the timing of mating relative to dispersal. Such information may never, however, provide evidence for inbreeding, for inbreeding may be avoided by ethological mechanisms. They merely provide evidence as to whether inbreeding could occur. In the case of $G$. depressa and D. bifasciata little was found on the ecology of adults.

\section{Oncopeltus fasciatus}

Females do not mate for 4-5 days after emergence as adults. Movement during this time may be either migratory or within local patch. A low level of inbreeding cannot be ruled out.

\section{Drosophila willistoni group}

Inbreeding avoidance has been cited as a maintaining factor in these species, with a minimum level of inbreeding of 10 per cent estimated as being necessary to maintain the element in the population (Ebbert, 1991). Allozyme studies of wild populations of these species show no significant dearth of heterozygotes (Ayala et al., 1972a, b, 1974; de Borba \& Napp, 1986). However, the fit of allozyme frequencies to Hardy-Weinberg equilibrium cannot be taken as a proof of random mating, the power of such tests to detect small departures from random mating being low (Ward \& Sing, 1970). Inbreeding depression in this species is high (Malogolowkin-Cohen et al., 1964). It has been argued that the high lethal load is indicative of a species where close inbreeding does not occur (inbreeding producing selection against such alleles) and population size is effectively infinite (Pavan et al., 1950 ). Studies of the ecology of $D$. willistoni suggest very large populations comprised of many areas of high population density with relatively low levels of dispersion between such areas (Burla et al., 1950). Taylor \& Powell (1983) picture D. willistoni populations as being like 'a tightly packed bed of nails with more free movement among sites than $D$. melanogaster'. This ecological description, along with the information from genetic variation over space, suggests that the level of inbreeding is low, but how low is unresolved.

\section{Drosophila bifasciata}

The data in Ikeda (1970) discussed above suggest that sex ratio individuals were more fit, in the absence of competition, than individuals from the normal strain. This is suggestive of an inbreeding effect. However, whether such an effect exists outside of laboratory populations is unknown. Nothing was found on the population structure of this species.

\section{Nasonia vitripennis, Caraphractus cinctus}

In both these species, males emerge from the host first and compete for access to the emerging females $(N$. vitripennis: King et al., 1969; C. cinctus: Jackson, 1966). Inbreeding levels are therefore high. However, outbreeding does occur. Male $N$. vitripennis displaced from their host puparia by siblings search for other parasitized puparia, and then defend these against other males to ensure access to the emerging females (King et al., 1969). Additionally, in the case of superparasitism, not all wasps emerging from a single puparium are related.

It is certainly true that inbreeding occurs, but it is also true that in haplodiploid insects such as $N$. vitripennis, where sex is not determined by simple sex determination alleles, inbreeding depression is lower, many deleterious recessive alleles being selected against in the hemizygous males (Crozier, 1970). However, an appreciable level still exists in some inbreeding haplodiploid organisms. For instance, in the facultatively inbreeding mite, Tetranychus urticae, breeding experiments have shown an inbreeding depression of around 7 per cent (Helle, 1965). Such a level probably derives from the presence of alleles whose expression is limited to females and which are therefore neutral in the hemizygous condition. The potential for such depression is seen in the high proportion of mutations in $N$. vitripennis which are sex limited (Saul et al., 1965). Therefore, inbreeding avoidance may provide an advantage to male killing in $N$. vitripennis. Inbreeding depression in $C$. cinctus is merely considered to be low (Jackson, 1966), and the situation here is less certain, although again, the presence of deleterious sex limited mutations would be expected to provide some level of depression.

The situation in both these species is complicated by the low rate of outbreeding at low host densities: when hosts are not aggregated, males from other puparia may not find all puparia. Females from clutches where male killing has been 100 per cent effective may then go 
unmated (King et al., 1969). Such unmated females would produce males only, and consequently extinction of the element in that line. Hurst (1993) also notes the partial penetrance of male killing by the bacterium: some males often survive. This further complicates the calculation of an advantage through inbreeding avoidance.

\section{Coccinellid beetles: Harmonia axyridis, Menochilius sexmaculatus, Adalia bipunctata}

Inbreeding depression in laboratory crosses of $A$. bipunctata is severe (Lus, 1947b), and is manifested by a decrease in egg hatch rate. Egg hatch rates in field populations in Cambridge are high, suggesting that inbreeding is low (G. D. D. Hurst, personal observation), although the precise level is unknown. A low level is also suggested by the large aggregations of ladybirds that occur. Populations of mating adults may be large ( 5000 on a single, continuous nettle bed: M. E. N. Majerus, personal observation). No relevant study on the other two species was found.

\section{Ips latidens}

Emerging adult female $I$. latidens are winged and disperse. The production of an aggregation pheromone, ipsenol, by males that have found suitable host trees, attracts other individuals to such sites to either mate (females) or to found separate galleries on the same tree (males). Traps baited with such pheromones may attract up to 300 adults (Miller et al., 1991). This habit of dispersal before mating, and the aggregation of females and males at breeding sites, suggest that inbreeding will be very low.

\section{Epiphyas postvittana}

After emergence as adults, calling by pheromones and mating occurs before dispersal (Gu \& Danthanarayana, 1990). Under conditions of low population size, the mating behaviour of this moth suggests that inbreeding may become common.

\section{Hypolimnas bolina}

Poulton (1928) hypothesized that male killing evolved in $H$. bolina as a method of inbreeding avoidance. However, the inbreeding status of this species is unknown.

\section{Spodoptera littoralis, Estigmene acrea, Cadra cautella}

Males are attracted to females in all these species by means of pheromones. The level of inbreeding will depend on the proportion of males in the vicinity of the female which are related to her. This will depend on specific population demography. All three species of moth are considered pests capable of devastating damage because of the large numbers which may exist. Such large numbers suggest that inbreeding may be low.

\section{Summary}

The level of inbreeding required to maintain the elements (as calculated from Werren's (1987) model) is usually less than 20 per cent. The existence of either a resource advantage or horizontal transmission will lower this figure. The hymenopterans $N$. vitripennis and C. cinctus are facultatively inbreeding species, which probably show low levels of inbreeding depression. The question of whether unmatedness is a problem for females from male killed clutches is, however, unresolved. The inbreeding status of other species is more ambiguous. Simple analyses of the fitness of females from sex ratio and non-sex ratio families cannot give an idea of whether inbreeding occurs, for early resource advantages and the direct effect of the symbiosis with the microbe on fitness through resource use may both be confounding variables. Large population sizes are suspected in some and, thus, in the absence of strongly demic population structures, inbreeding will be low (S. littoralis, E. acrea, D. willistoni). In E. postvittana, mating occurs before dispersal. If individuals mate randomly, there may be a low level of inbreeding in this system.

\section{Horizontal transmission}

The spontaneous arisal of male killing traits in previously uninfected lines has been recorded in the four cases detailed below, and explained by horizontal transmission of the male killing element between individuals. In two others (D. willistoni, E. postvittana) there is a positive assertion that horizontal transmission was not found (Ebbert, 1991; Geier et al. 1978), and in D. bifasciata it is considered unlikely, owing to the large difficulties encountered in performing artificial transfers in the laboratory (Ikeda, 1970). In other cases, no note is made of horizontal transmission. It is hard to rule out the presence of such transmission, however, for laboratory reared lines are kept separated from others, possibly preventing a naturally occurring mechanism of horizontal transfer.

\section{Nasonia vitripennis}

Horizontal transfer of the male killing element may occur when an uninfected female super-parasitizes a 
puparium previously utilized by an infected female, the bacterium being taken up per-orally (Skinner, 1985). The rate of such transfer in the wild will critically depend on the rate of super-parasitism, which is unknown, although likely to depend on host density. It is also tempting to hypothesize that a similar mechanism might exist in $C$. cinctus.

\section{Hypolimnas bolina}

Horizontal transmission of the male killing element is strongly suspected in $H$. bolina, although the rate of this is unknown. One of 189 females derived from bisexual broods gave rise to a heritable unisexual brood (Clarke et al., 1975). A source of infection from another species has also been hypothesized (Clarke et al., 1983).

\section{Spodoptera littoralis}

Horizontal transmission of the sex ratio trait is suspected in this system, one cross from a previously bisexual line showing the sex ratio trait in a heritable fashion.

\section{Estigmene acrea}

Horizontal transmission of the element is suspected, three bisexual laboratory lines developing and maintaining the sex ratio trait. Egg cannibalism was shown not to be a source of such cross-infection.

\section{Summary}

No evidence for a benefit of early male killing through increased horizontal transmission exists. In the cases where horizontal transmission is seen, there is either evidence against the role of dead male eggs (E. acrea) or no positive evidence for their role. In other systems, transfer through the gut has either been excluded $(D$. willistoni) or considered unlikely $(D$. bifasciata). More work needs to be carried out in this area, but it appears unlikely that elements which are specialized to the internal cellular environment will survive gut passage.

\section{Discussion}

The distortion of sex ratios by cytoplasmically inherited microorganisms is well known in insects and Crustacea (see Hurst, 1993 for review). Such distortion may be of the primary sex ratio through alteration of patterns of fertilization or sexuality in Hymenoptera (Skinner, 1982; Stouthamer et al., 1990) or the feminization of genetically male individuals in
Crustacea (Legrand et al., 1987). In these cases, it is clear that the agent spreads because such action leads to the production of more females, the sex through which it can pass. Is male killing an analogous behaviour, increasing the survivorship of females through which the element can pass? Certainly in the case of late male killing, there is strong evidence that the rationale is subtly different, male killing being associated with the exit of the individual out of the male line to infect other individuals. However, little evidence exists of such movement associated with male death for early male killers: the microbe appears to die with its host. Male killing in these systems must therefore be analogous to primary sex ratio distortion, through altering patterns of survival, or non-adaptive, the male killing element being maintained through horizontal transmission unassociated with male death.

The above descriptions suggest that in certain species, direct evidence for analogy to primary sex ratio distortion exists. The ecologies of $O$. fasciatus, $C$. cinctus, I. latidens, the coccinellid beetles and E. postvittana all provide evidence for an early resource advantage. The ecologies of other species are consistent with it (egg cannibalism, aggregations of early instar larvae). Inbreeding avoidance probably provides an advantage in $N$. vitripennis and possibly in $C$. cinctus and $E$. postvittana. It is doubtful, however, whether advantages through inbreeding avoidance exist in many diploid species, inbreeding being less common here. Certain species show little evidence of either a resource or inbreeding avoidance advantage, although their ecology may bear more close scrutiny.

While direct evidence for the adaptive nature of male killing may be sought in the ecologies of the species concerned, indirect evidence may come from an examination of rates of horizontal transfer of these elements between species independently of male killing. As the inefficiency of vertical transmission increases, so the level of horizontal transmission required to maintain the element will increase if horizontal transmission is the only factor maintaining the microbe in the population. If the level of horizontal transmission that occurs independently of male death were below this level, then some other factor must be important. Given no positive effect of infection, such a factor must be associated with male death. The question arises, therefore, as to the level of horizontal transmission. The spontaneous arisal of male killing is known in some of these systems, and may reflect horizontal transmission. However, alternative explanations, based on dosage related effects of the male killing agent causing its occasional obscurement within a line but later re-occurrence, must also be tested. However, even if such occurrence is presumed to be due to horizontal 
transfer, the information that exists on the level of such transfer derives from laboratory studies and is unlikely to accurately reflect the levels of horizontal transmission in the wild. It is therefore impossible to use this approach at this time. The importance of levels of horizontal transfer in this context places a pressing need on the evaluation of natural rates of horizontal transmission. Investigation of correlations between maternal lineages, as detected by mitochondrial DNA variation, and lineages of the microbe would provide some details of horizontal transfer processes. A high level of correlation between microbe variants and maternal lineage would be evidence for a very low level of natural horizontal transmission of the element within a species, and vice versa.

Direct evidence for a fitness effect of early male killing on the remaining larvae is strong is some cases, suggesting analogy with primary sex ratio distortion. Other species have ecologies compatible with such effects. Clearly, much is still unknown about these systems. The evidence for the adaptive significance of male killing has derived from experiments and observations not designed for critical examination of hypotheses concerning the adaptive function of male killing. Experiments designed directly to test such hypotheses must prove a fruitful avenue for future research.

\section{Acknowledgements}

We thank Dr Jack Werren for discussions of the role of inbreeding in maintaining male killing elements, and the problems associated with measuring this factor, $\mathrm{Dr}$ Laurence Hurst for discussion of male killers and intragenomic conflict, and an anonymous reviewer for comments on the manuscript. Greg Hurst is the recipient of a grant from the SERC.

\section{References}

AGARWALA, B. K. 1991. Why do ladybirds (Coleoptera: Coccinellidae) cannibalize? J. Biosci., 16, 103-109.

ANDRE, F. 1934. Notes on the biology of Oncopeltus fasciatus (Dallas). Iowa State Coll. J. Sci., 9, 73-87.

AYALA, F. J., POWELL, J. R., TRACEY, M. L., MOURAO, C. A. AND PEREZSALAS, s. 1972a. Enzyme variability in the Drosophila willistoni group. III. Genic variation in natural populations of Drosophila willistoni. Genetics, 70, 113-139.

AYAlA, F. J., POWELL, J. R. AND TRACEY, M. L. 1972b. Enzyme variability in the Drosophila willistoni group. V. Genic variations in natural population of Drosophila equinoxalis. Genet. Res., Camb., 20, 19-42.

AYALA, F. J., TRACEY, M. L., BARR, L. G. AND EHRENFELD, J. G. 1974. Genetic and reproductive differentiation of the sub- species, Drosophila equinoxalis carribiensis. Evolution, 28, 24-41.

BANKS, C. J. 1955. An ecological study of Coccinellidae (Col.) associated with Aphis fabae Scop. on Vicia fabia. Bull. Ent. Res., 46, 561-587.

BANKs, C. J. 1956 . Observations on the behaviour and mortality in Coccinellidae before dispersal from the egg shells. Proc. R. Ent. Soc. Lond.(A), 31, 56-60.

BIRCH, L. C. AND BatTaglia, B. 1957. The abundance of Drosophila willistoni in relation to food in natural populations. Ecology, 38, 165-166.

BIShara, I. 1934. The cotton worm, Prodenia litura F, in Egypt. Bull. Soc. R. Ent. d'Egypte, 18, 288-416.

BONGERS, J. AND EGgERMANN, w. 1971. Der Einfluß des Subsozialverhaltens der spezialisierten Samensauger Oncopeltus fasciatus Dall. und Dysdercus fasciatus Sign. auf ihre Ernahrung. Oecologia, 6, 293-302.

BRIMACOMBE, L. C. 1980. All-female broods in field and laboratory populations of the Egyptian cotton leafworm, Spodoptera littoralis (Boisduval) (Lepidoptera: Noctuidae). Bull. Ent. Res., 70, 475-481.

BURLA, H., DA CUNHA, A. B., CALCAVANTI, A. G. L., DOBZHANSKY, TH. AND PAVAN, C. 1950. Population density and dispersal rates in Brazilian Drosophila willistoni. Ecology, 31, 393-404.

CHANG, K. S. AND MORIMOTO, N. 1988. Life table studies of the walnut leaf beetle, Gastrolina depressa (Coleoptera: Chrysomelidae), with special attention to aggregation. Res. Popul. Ecol., 30, 297-313.

CHANG, K. S., SHIRAISHI, T., NAKASUJI, F. AND MORIMOTO, N. 1991. Abnormal sex ratio condition in the Walnut leaf beetle, Gastrolina depressa (Coleoptera: Chrysomelidae). Appl. Ent. Zool., 26, 299-306.

ClARKE, C., JOHnSton, G. AND JOHnSton, B. 1983. All female broods in Hypolimnas bolina $\{\mathrm{L}$.$\} . A resurvey of West Fiji$ after 60 years. Biol. J. Linn. Soc., 19, 221-235.

ClARKE, C., SHEPPARD, P. M. AND SCALI, v. 1975. All female broods in the butterfly Hypolimnas bolina (L.) Proc. $R$. Soc. Lond. B., 189, 29-37.

CROZIER, R. H. 1970. On the potential for genetic variability in haplodiploidy. Genetica, 41, 551-556.

DANTHANARAYANA, w. 1975. The bionomics, distribution and host range of the light brown apple moth, Epiphyas postvittana (Walk.)(Tortricidae). Aust. J. Zool., 23, 419-437.

Danthanarayana, w. 1983. Population ecology of the light brown apple moth, Epiphyas postvittana (Lepidoptera: Tortricidae). J. Anim. Ecol., 52, 1-33.

DE BORBA, C. M. B. AND NAPP, M. 1986. Genetic-ecologic correlations in the enzyme variability of Drosophila willistoni. Rev. Bras, de Gen., 9, 593-614.

DINGLE, H. 1968. Life history and population consequences of density, photo-period, and temperature in a migrant insect, the milkweed bug, Oncopeltus. Am. Nat., 102, 149-163.

DIXON, A. F. G. 1970. Factors limiting the effectiveness of the coccinellid beetle, Adalia bipunctata (L.), as a predator of the sycamore aphid Drepanosiphum platanoides (Schr.) J. Anim. Ecol., 39, 739-751.

EARLE, N. W. AND MACFARLANE, J. 1968. A unisexual strain of the salt marsh caterpillar, Estigmene acrea. Ann. Ent. Soc. Am., 61, 949-953. 
EBBERT, M. 1991. The interaction phenotype in the Drosophila willistoni-spiroplasma symbiosis. Evolution, 45, 971-988.

GEIER, P. W. AND BRIESE, D. T. 1980. The light brown apple moth, Epiphyas postvittana (Walker). 4. Studies on population dynamics and injuriousness to apples in Australian Capital Territory. Austr. J. Ecol., 5, 63-93.

GEIER, P. W., BRIESE, D. T. AND LEWIS, T. 1978. The light brown apple moth Epiphyas postvittana (Walker). 2. Uneven sex ratios and a condition contributing to them in the field. Austr. J. Ecol., 3, 467-488.

GHERNA, R. L., WERREN, J. H., WEISBURG, W., COTE, R., WOESE, C. R., MANDELCO, L. AND BRENNER, D. J. 1991. Arsenophus nasoniae gen.-nov., sp.-nov., the causative agent of the son killer trait in the parasitic wasp Nasonia vitripennis. Int. J. Syst. Bact., 41, 563-565.

GORDON, D. M. AND STEWART, R. K. 1988. Demographic characteristics of the stored products moth Cadra cautella. J. Anim. Ecol., 57, 627-644.

GOTOH, T. AND NIJIMA, K. 1986. Characteristics and agents of abnormal sex ratios (SR) in two aphidophagous coccinellid species. In: Hodek, I. (ed.), Ecology of the Aphidophaga, Academia, Prague, pp. 545-550.

GRANT, B., BURTON, S., CONTOREGGI, C. AND ROTHSTEIN, M. 1980. Outbreeding via frequency-dependent mate selection in the parasitoid wasp, Nasonia $(=$ Mormoniella $)$ vitripennis Walker. Evolution, 34, 983-992.

GU, H. AND DANTHANARAYANA, w. 1990. Age related flight and reproductive performance of the light brown apple moth, Epiphyas postvittana. Entomol. Exp. Appl., 54, 109-115.

HACKETT, K. J., LYNN, D. E., WLLIAMSON, D. L., GINSBERG, A. S. AND WHITCOMB, R. F. 1985. Cultivation of the Drosophila spiroplasma. Science, 232, 1253-1255.

HELLE, w. 1965. Inbreeding depression in an arrhenokotous mite, Tetranychus urticae. Ent. Exp. Appl., 8, 299-304.

HEMPTINE, J-L., DIXON, A. F. G. AND COFFIN, J. 1992. Attack strategies of ladybird beetles (Coccinellidae): factors shaping their numerical response. Oecologia, 90, 238-245.

HILL, D. S. 1987. Agricultural Insect Pests of Temperate Regions and Their Control. Cambridge University Press, Cambridge.

HINDS, w. E. 1904. Life history of the salt marsh caterpillar (Estigmene acrea Dru.) at Victoria, Tex. U.S. Dept. Agric. Div. Entomol. Bull., 44, 80-84.

HU, K. 1979. Maternally inherited 'sonless' abnormal sex ratio condition in the ladybeetle Harmonia axyridis. Acta Genet. Sin., 6, 296-304.

HURST, G. D. D., MAJERUS, M. E. N. AND WALKER, L. E. 1992. Cytoplasmic male killing elements in Adalia bipunctata (Linnaeus) (Coleoptera: Coccinellidae). Heredity, 69, 84-91.

HURST, G. D. D., MAJERUS, M. E. N. AND WALKeR, L. E. 1993. The importance of cytoplasmic male killing elements in natural populations of the two spot ladybird, Adalia bipunctata (Linnaeus) (Coleoptera: Coccinellidae). Biol. J. Linn. Soc. (in press).

HURST, G. D. D., BOURKE, D., ELLIOTT, R., HUDSON, E., IRVING, W., NICHOLSON, J., PEARSON, M., RANSFORD, M., SANDS, Z., SLOGGETT, J., WALKER, L. E. AND MAJERUS, M. E. N. (in prep). Evidence for a resource advantage to male killing behaviour of bacteria in Adalia bipunctata.

HURST, L. D. 1991. The incidences and evolution of cytoplasmic male killers. Proc. R. Soc. Lond. B., 244, 91-99.

HURST, L. D. 1993. The incidences, mechanisms and evolution of cytoplasmic sex ratio distorters in animals. Biol. Reviews, 68, 121-193.

IKEDA, H. 1970. The cytoplasmically-inherited 'sex-ratio' condition in natural and experimental populations of Drosophila bifasciata. Genetics, 65, 311-333.

JACKSON, D. J. 1956. Notes on Hymenopterous parasites bred from eggs of Dytiscidae in Fife. J. Soc. Br. Ent., 5, 144-149.

JACKSON, D. J. 1958. Observations on the biology of Carnaphractus cinctus Walker (Hymenoptera: Mymaridae), a parasitoid of the eggs of Dytiscidae. I. Methods of rearing and numbers bred on different host eggs. Trans. $R$. Ent. Soc. Lond., 110, 533-554.

JACKSON, D. J. 1961. Observations on the biology of Carnaphractus cinctus Walker (Hymenoptera: Mymaridae), a parasitoid of the eggs of Dytiscidae. II. Immature stages and seasonal history with a review of Mymarid larvae. Parasitology, 51, 269-294.

JACKSON, D. J. 1966. Observations on the biology of Carnaphractus cinctus Walker (Hymenoptera: Mymaridae), a parasitoid of the eggs of Dytiscidae. III. The adult life and sex ratio. Trans. $R$. Ent. Soc. Lond., 118, 23-49.

KAWAI, A. 1978. Sibling cannibalism in the first instar larvae of Harmonia axyridis Pallas (Coleoptera, Coccinellidae). Kontyû, 46, 14-19.

KIMURA, M. T., TODA, M. J., BEPPU, K. AND WATABE, H. 1977. Breeding sites of Drosophilid flies in and near Sapporo, Northern Japan, with supplementary notes on the adult feeding habits. Kontyu , 45, 571-582.

KING, P. E., ASKEW, R. R. AND SANGER, C. 1969. The detection of parasitised hosts by males of Nasonia vitripennis (Walker) (Hymenoptera: Pteromalidae) and some possible implications. Proc. R. Ent. Soc. Lond. A, 44, 85-90.

KIRKENDALL, L. R. 1989. Within-harem competition between Ips females, an overlooked component of density-dependent larval mortality, Holarct. Ecol., 12, 477-487.

LANIER, G. N. AND OLIVER, J. H. 1966. Sex ratio condition: unusual mechanism in bark beetles. Science, 153, 208-209.

LANIER, G. N. 1966. Interspecific mating and cytological studies of closely related species of Ips DeGeer and Orthotomictus Ferrari (Coleoptera: Scolytidae). Can. Ent., 98, 175-188.

LEGRAND, J. J., LEGRAND-HAMELIN, E. AND JUCHAULT, P. 1987. Sex determination in Crustacea. Biol. Rev., 62, 439-470.

LESLIE, T. F. 1984. A sex ratio condition in Oncopeltus fasciatus. J. Hered., 75, 260-264.

LEVENTHAL, E. A. 1965. A study of the 'sex-ratio' condition in Drosophila bifasciata. Am. Zool., 5, 649.

LEWIS, D. 1941. Male sterility in natural populations of hermaphroditic plants: the equilibrium between females and hermaphrodites to be expected with different types of inheritance. New Phytol., 40, 56-63. 
LUS, Y. Y. 1947a. Some aspects of the population increase in Adalia bipunctata 2. The strains without males. Dokl. Akad. Nauk SSSR, 57, 951-954.

LUS, Y. Y. $1947 \mathrm{~b}$. Some rules of reproduction in populations of Adalia bipunctata: heterozygosity of lethal alleles in populations. Dokl. Akad. Nauk SSSR, 57, 825-828.

MACLELLAN, C. R. 1973. Natural enemies of the light brown apple moth, Epiphyas postvittana, in the Australian capital territory. Can. Ent., 105, 681-700.

MAGNI, G. E. 1953. 'Sex-ratio': a non-Mendelian character in Drosophila bifasciata. Nature, 172, 81.

MAGNI, G. E. 1954. Thermic cure of cytoplasmic 'sex-ratio' in Drosophila bifasciata. Caryologia (Suppl.), 6, 1213-1216.

MAGNI, G. E. 1959. Il carattere sex ratio in popolazioni naturali ed artificiali di Drosophila bifasciata. 1st Lombardo (Rend. Sci.), 93, 103-116.

MALOGOLOWKIN-COHEN, CH., LEVENE, H., DOBZHANSKY, N. P. AND SIMMONS, A. S. 1964. Inbreeding and mutational load in natural populations of Drosophila willistoni. Genetics, 50, 1299-1311.

MATHEW, G. F. 1888. Life histories of Rhopalocera from the Australian region. Trans. Ent. Soc. Lond., 1888, 137-138.

MATSUKA, M., HASHI, H. AND OKADA, I. 1975. Abnormal sex ratio found in the lady beetle Harmonia axyridis Pallas (Coleoptera: Coccinellidae). Appl. Entomol. Zool., 10, 84-89.

MILLER, D. R. AND BORDEN, J. H. 1985. Life history and biology of Ips latidens (Leconte) (Coleoptera: Scolytidae). Can. Ent., 117, 859-871.

MILLER, D. R., BORDEN, J. H., KING, G. G. S. \& SLESSOR, K. N. 1991. Ipsenol: an aggregation pheromone for Ips latidens (Leconte) (Coleoptera: Scolytidae). J. Chem. Ecol., 17, 1517-1527.

NG, S. M. 1986. Effects of first instar cannibalism on the first instar larvae of four species of aphidophagous Coccinellidae. In: Hodek, I. (ed.), Ecology of the Aphidophaga, Academia, Prague, pp. 69-75.

NIIJIMA, K. AND NAKAJIMA, K. 1981. Abnormal sex ratio in Menochilius sexmaculatus (Fabricius). Bull. Fac. Agric. Tamagawa Univ., 21, 59-67.

NIIJIMA, K. 1983. Experimental transfer of abnormal sex ratio in two ladybird species. Bull. Fac. Agric. Tamagawa Univ., 23, 11-17.

OSAWA, N. 1989. Sibling and non-sibling cannibalism by larvae of a lady beetle Harmonia axyridis Pallas (Coleoptera: Coccinellidae) in the field. Res. Popul. Ecol., 31, 153-160.

osAwA, N. 1992. Sibling cannibalism in the ladybird beetle Harmonia axyridis: fitness consequences for mother and offspring. Res. Popul. Ecol., 34, 45-55.

PAVAN, C., CORDEIRO, A. R., DOBZHANSKY, N., DOBZHANSKY, TH., MALOGOLOWKIN, C., SPASSKY, B. AND WEDEL, M. 1950. Concealed genic variability in Brazilian populations of Drosophila willistoni. Genetics, 36, 13-30.

POULTON, E. B. 1928. Adaptations which discourage inbreeding in Lepidoptera and other insects. Proc. R. Ent. Soc. Lond., 3, 18-20.

RALPH, C. P. 1976. Natural food requirements of the large milkweed bug, Oncopeltus fasciatus (Hemiptera: Lygaediae), and their relation to gregariousness and host plant morphology. Oecologia, 26, 157-173.
RALPH, C. P. 1977. Effect of host plant density on populations of a specialized, seed sucking bug, Oncopeltus fasciatus. Ecology, 58, 799-809.

SAUER, D. AND FEIR, D. 1973. Studies on natural populations of Oncopeltus fasciatus (Dallas), the large milkweed bug. Am. Midl. Nat., 90, 13-37.

SAUL, G., Whiting, P. W., SAUL, S. W. AND HEIDNER, C. A. 1965. Wildtype and mutant stocks of Mormoniella. Genetics, $\mathbf{5 2}$, 1317-1327.

SIMMONDS, H. w. 1923a. Families of Hypolimnas bolina L. bred from known female parents from different Fijian islands. Trans. R. Ent. Soc. Lond., 1923, 651-662.

SIMMONDS, H. w. 1923b. All female families of Hypolimnas bolina L., bred in Fiji by H. W. Simmonds. Proc. R. Ent. Soc. Lond., 1923, ix-xii.

SIMMONDS, H. w. 1926. Sex ratio of Hypolimnas bolina L., in Viti Levu, Fiji. Proc. R. Ent. Soc. Lond., 1, 29-32.

SIMMONDS, H. w. 1928. Mr H. W. Simmonds' conclusion that all-female-producing females form a persistent strain in Suva. Proc. R. Ent. Soc. Lond., 3, 43-44.

SIMMONDS, H. W. 1930. Further notes on Hypolimnas bolina $\mathbf{L}$. in Fiji. Proc. R. Ent. Soc. Lond., 5, 75-77.

SKINNER, S. W. 1982. Maternally inherited sex ratio in the parasitoid wasp Nasonia vitripennis. Science, 215, 1133-1134.

SKINNER, S. w. 1985. Son-killer: a third extrachromosomal factor affecting sex ratios in the parasitoid wasp Nasonia vitripennis. Genetics, 109, 745-754.

SOKOLOFF, A. 1966. Morphological variation in natural and experimental populations of Drosophila pseudoobscura and Drosophila persimilis. Evolution, 20, 49-71.

STOUTHAMER, R., LUCK, R. F. AND HAMILTON, w. D. 1990. Antibiotics cause parthenogentic Trichogramma Hymenoptera/ Trichogrammatidae to revert to sex. Proc. Natl. Acad. Sci. U.S.A., 87, 2424-2427.

TAKAHASI, F. AND KUWAHARA, Y. 1970. Studies on sex pheromones in the Pyralidae. III. The inheritance of the abnormal sex ratio condition in a strain of the almond moth Cadra cautella Walker (Pyctinae). Botyu-Kagaku, 35, 11-21.

TAYLOR, C. E. AND POWELL, J. R. 1983. Population structure of Drosophila: genetics and ecology. In: Ashburner, M., Carson, H. L. and Thompson, J. N. (eds), The Genetics and Biology of Drosophila, Vol. 3, Academic Press, pp. 29-59.

UYENOYAMA, M. K. AND FELDMAN, M. w. 1978. The genetics of sex ratio distortion by cytoplasmic infection under maternal and contagious transmission: an epidemiological study. Theor. Popul. Biol., 14, 471-497.

VANE-WRIGHT, R. I., ACKERY, P. R. AND SMILES, R. L 1977. The polymorphism, mimicry and host plant relationships of Hypolimnas butterflies. Biol. J. Linn. Soc., 9, 285-297.

WARD, R. H. AND SING, C. F. 1970 . A consideration of the power of the $\chi^{2}$ test to detect inbreeding effects in natural populations. Am. Nat., 104, 355-365.

WERREN, J. H. 1987. The coevolution of autosomal and cytoplasmic sex ratio factors. J. Theor. Biol., 124, 317-334.

WERREN, J. H., SKINNER, S. W. AND HUGER, A. M. 1986. Male killing bacteria in a parasitic wasp. Science, 231, 990-992.

WILLIAMSON, D. L. AND POULSON, D. F. 1979. Sex ratio organisms (Spiroplasmas) of Drosophila. In: R. F. Whitcomb and 
J. G. Tully (eds), The Mycoplasmas, vol. III, Academic Press, New York, pp. 175-208.

WRATTEN, S. D. 1973. The effectiveness of the coccinellid beetle, Adalia bipunctata (L.) as a predator of the lime aphid, Eucallipterus tiliae L. J. Anim. Ecol., 42, 785-802. WRATTEN, S. D. 1976. Searching by Adalia bipunctata (L.)

(Coleoptera: Coccinellidae) and escape behaviour of its aphid and ciccadellid prey on lime (Tilia $\times$ vulgaris Hayne). Ecol. Entomol., 1, 139-142.
YOUNG, w. R. AND A SIFUENTES, J. A. 1959. Biological and control studies on Estigmene acrea (Drury), a pest of corn in the Yaqui valley, Sonora, Mexico. J. Econ. Ent., 52, 1109-1111.

ZAHER, M. A. AND MOUSSA, M. A. 1961. Effects of population density on Prodenia litura (Lepidoptera: Noctuidae). Ann. Ent. Soc. Am., 54, 145-149. 